\title{
炎部位より発毛を認めた毛周期停止のポメラニアンの 1 例 \\ A case of pomeranian with hair cycle arrest presented hair growth at the moxibustion site
}

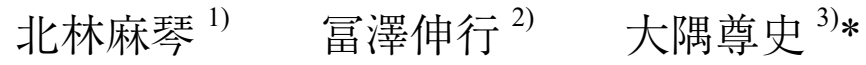 \\ 1) ひまわり動物病院， ${ }^{2)}$ とみざわ動物病院， 3) 東京農工大学 \\ Makoto Kitabayashi $^{1)}$, Nobuyuki Tomizawa ${ }^{2)}$, Takafumi Osumi ${ }^{3) *}$ \\ ${ }^{1)}$ Himawari Animal Hospital, ${ }^{2)}$ Tomizawa Animal Hospital, ${ }^{3)}$ Tokyo University of Agriculture and Technology
}

Received February 1, 2020 and accepted June 22, 2020

キーワード : 尒, 毛周期停止, ポメラニアン

Key words: moxibustion, hair cycle arrest, Pomeranian

毛周期停止症は特にポメラニアンに好発する 体幹部を中心とした非炎症性脱毛症であり，全 身症状や内分泌異常を伴わないことが特徵的で, Alopecia X もしくは脱毛症 X とも呼ばれている ${ }^{1)}$ 本疾患の原因は完全に解明されておらず，これま でにメラトニンやトリロスタンの内服治療をはじ め, フィナステリド, メドロキシプロゲステロン 酢酸エステル，デスロレリンなどのホルモン調整 剤などの効果が示されているが, 根治的な治療法 は確立されていない1)。また，本疾患は皮膚生検 や外傷後に刺激部位に限局して発毛を認める場合 があることが知られており, 近年ではマイクロニー ドルを用いて刺激することで発毛させる治療法も 報告されている2)。一方で，マイクロニードルを 用いた治療は全身麻酔の必要性や施術に伴う侵襲 の大きさが問題となることがあり，より低侵襲な 治療法の確立が求められている。

炎は，皮膚表面で艾（もぐさ）を燃焼させる， 一般的に使用される伝統的な中医学の一つであ

*連絡先 : 大隅尊史 (東京農工大学農学部付属動物医療 センター)

₹ 183-8509 東京都府中市幸町 3-5-8

TEL 042-367-5785 FAX 042-367-5602

E-mail:w5110101@edu.gifu-u.ac.jp

* Correspondence to: Takafumi Osumi (Tokyo University of Agriculture and Technology) 3-5-8 Saiwai-cho, Fuchu, Tokyo 1838509, Japan
る ${ }^{3,4)}$ 。経穴 (ツボ) と呼ばれる特定の部位および それをつないだ経絡に対して温熱刺激を与えるこ とにより生理動態を変化させることにより疾病を

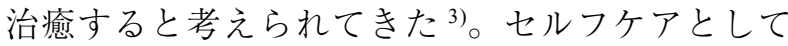
の自己施炎も行われ，自己施尒のための間接尒と 言われる様々な形の製品（棒炎やせんねん炎など） があり，直接艾を燃やす方法に比べ輻射熱を用い ているため安全性も高くなっている。本治療法は, その加温や局所刺激によって, 鎮痛効果や血管拡 張による血流増加を促し, 皮膚局所浅層の血管だ けでなく，深部組織掞よび遠位血管の微小循環を 改善することが示唆されている4)。また，マウスに おいては炎刺激により無刺激に比べ組織像におい て毛包数の増加, 毛母細胞の増加, 核分裂像が観 察され発毛の程度にも差が認められている5 。今回, 毛周期停止と診断され脱毛が持続しているポメラ ニアンに尒を行ったところ, 処置部位を中心に迅 速な発毛を認めたためその詳細を報告する。

症例は去勢雄, 4 歳 6 か月齢のポメラニアンで, 2 歳齢頃より背部を中心とする汎発性の脱毛を認 めていた。本症例は, 過去に他院にて一般血液検査, 内分泌検查および病理組織学的検査が実施され, それによって甲状腺機能低下症および副腎皮質機 能充進症が否定され，毛周期停止と診断された。 その後, トリロスタン (商品, 用量不明), レボチ ロキシンナトリウム水和物（チラーヂン S $50 \mu \mathrm{g}$, あすか製薬株式会社，東京，50 $\mu \mathrm{g} ， 1$ 日 2 回），に 


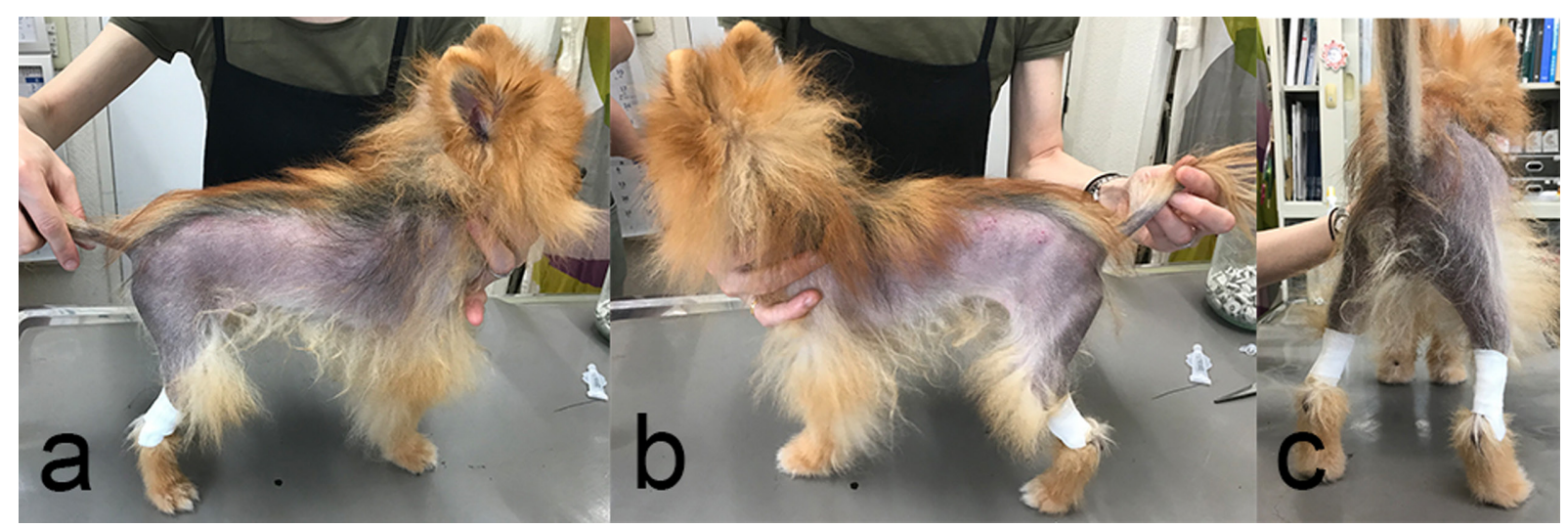

図 1 初診時の臨床所見

よる内服治療が施されたが，数か月間発毛した後 に再び脱毛し，その後の発毛は認めなかった。当 院初診時（第 1 病日）, 特に腰背部両側面から大腿 後縁におよぶ広範囲な脱毛および色素沈着, 軽度 の鱗屑が認められた（図 1)。皮膚捺印検査による 細胞診, 毛検査に扮いて球菌, 真菌, 寄生虫は認 められず，毛構造の異常も認められなかった。完 全血球検査, 血液生化学検査, 甲状腺ホルモン検 査（T4）に扔いても特記事項は認められなかった。 そこで，第 1 病日に脊柱を中心として左右両側に 頚部～尾部まで 3-4 cm おきに炎（せんねん尒オフ にんにくきゅう近江，せんねん炎株式会社，滋賀） を設置, 5 分程度加温した (図 2)。設置部位は経 絡ではいわゆる後肢太陽膀胱系経に準ずるが, 安 全性を考慮した設置部位とした。炎の際, 多少の 違和感を覚えるような動きはあったものの保定に より安定して処置を受けられる程度であった。本 症例は, 同時に内服として酢酸オサテロン（ウロ エース, あすかアニマルヘルス株式会社, 東京, 0.04 $\mathrm{mg} / \mathrm{kg}, 1$ 日 2 回), メラトニン (Melatonin now, NY, USA, $1 \mathrm{mg}, 1$ 日 2 回), 複合パントテン酸製剤 (デルパント配合顆粒, 陽進堂, 富山県, $5 \mathrm{mg} / \mathrm{kg}$, 1 日 2 回), レチノール (チョコラ A, エーザイ株 式会社, 東京, 200 単位 $/ \mathrm{kg}, 1$ 日 2 回), トコフェロー ル酶酸エステル（ユベラ, エーザイ株式会社, 東京, $20 \mathrm{mg} / \mathrm{kg}, 1$ 日 2 回), グルコン酸亜鉛（サンファ ン Z, Meiji Seika ファルマ, 東京, $0.1 \mathrm{~g}, 1$ 日 2 回), 海藻エキスサプリメント（アルギチャンプ, 神協産業株式会社, 山口県, $0.1 \mathrm{~g}, 1$ 日 2 回), 分 岐鎖アミノ酸（アミノピュア, AHS 合同会社, 東 京, $0.5 \mathrm{~g}, 1$ 日 2 回), 微細藻類由来不飽和脂肪酸 含有オイル（アルジェオメガ, AHS 合同会社, 東京, 1 カプセル, 1 日 1 回）を, 外用療法としてフィト スフィンゴシン（デュクソピペット, セバ社, フ

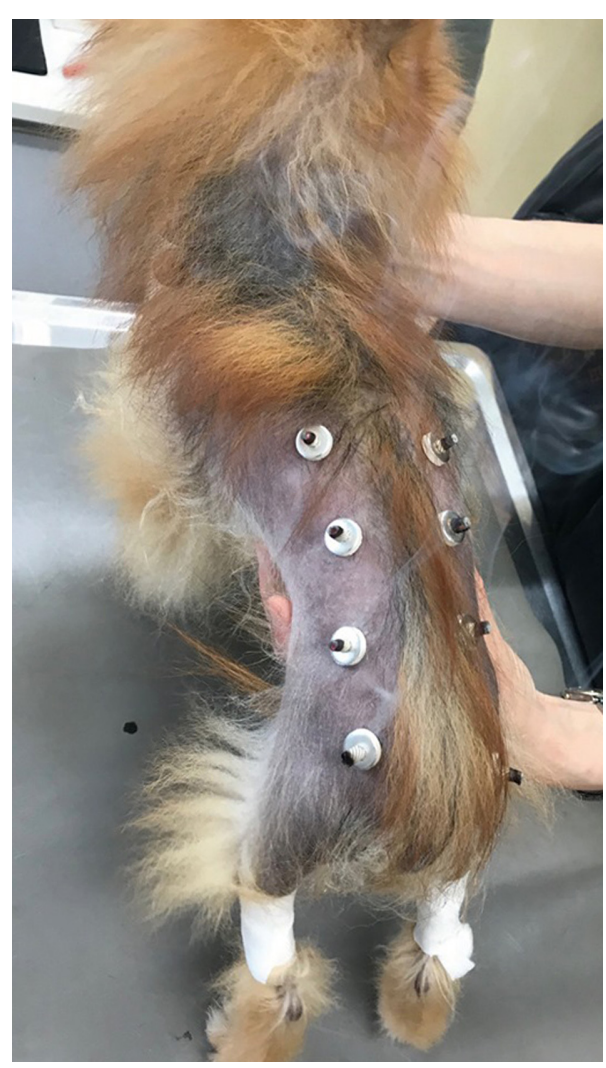

図 2 尒処置の様子. 自立した状態で処置が可能

ランス， $1 / 2$ 本，週 1 回塗布）を開始した。初診日 以降の経過として, 処置後 $4 \sim 5$ 日間は処置部位 に紅斑および微小な痂疲を認めたが, 数日で消失 した。その後, 処置後 3 週間で処置部位を中心に 顕著な発毛が認められた。特に痂疲を認めた部位 での発毛が顕著であった。第 39 病日には処置部位 に $0.5 \sim 1 \mathrm{~cm}$ 程度の発毛を認め, 処置部位周囲に も発毛が認められたため, 発毛部から場所をずら して再度尒を行った。痂疲を認めた部分にも発毛 


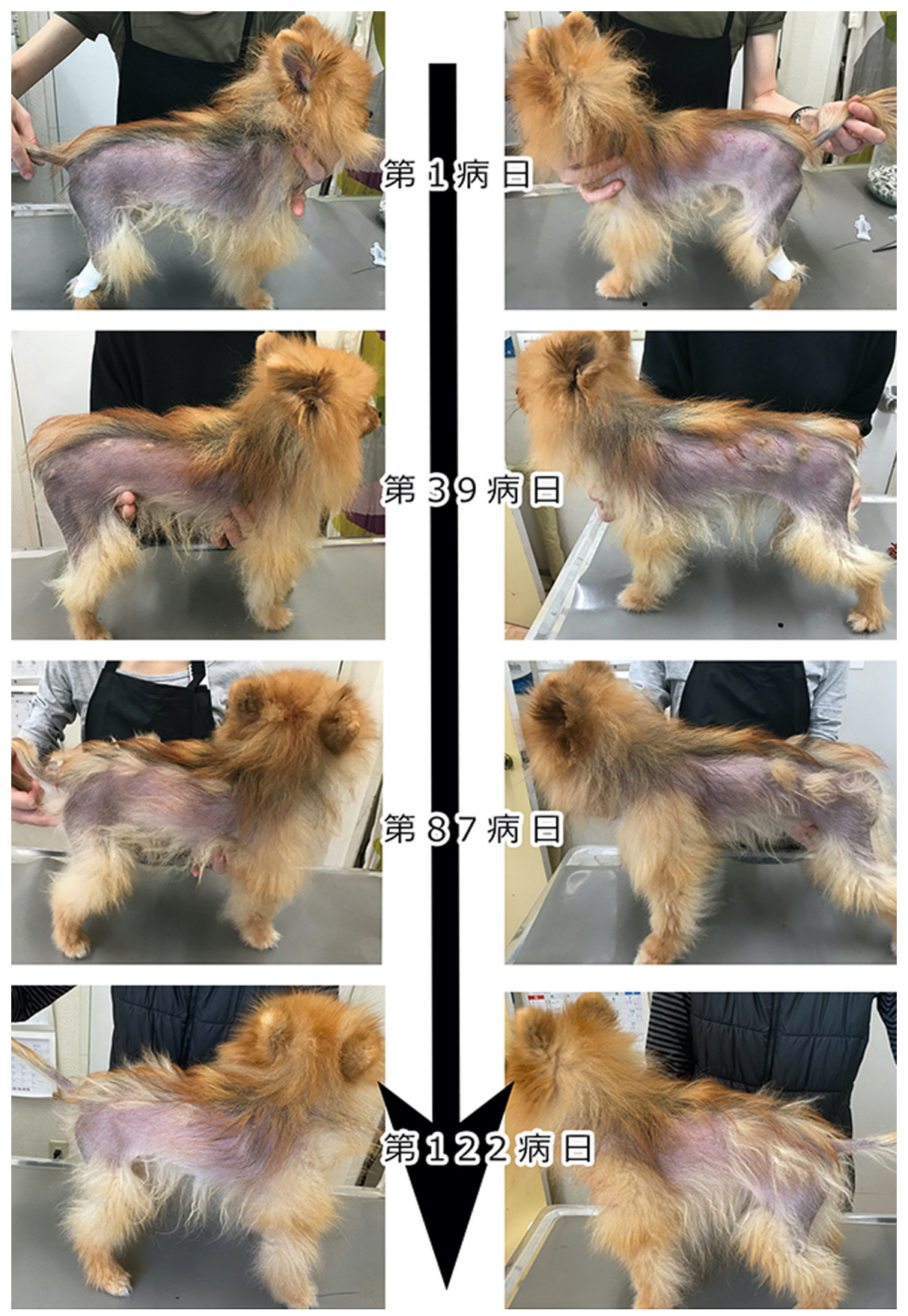

図 3 処置後の経過

は認められたが, 症例が処置部を自傷する問題が 生じたため，処置後に紅斑を認めた部分に $1 \%$ 才 ルビフロキサシン， $1 \%$ ミコナゾール硝酸塩， $0.1 \%$ トリアムシノロンアセトニド配合クリーム（ビク タス S MT クリーム, DS ファーマアニマルヘルス, 大阪）を 1 日 1 回の頻度で塗布したところ, 紅斑 は速やかに消失し痂疲は認めなかった。飼い主の 都合により約 3 週間内服薬の投与が不十分な時期 があったが, 第 87 病日には第 1 病日の処置部の被
毛は $5 \mathrm{~cm}$ 程度, 第 39 病日の処置部の被毛は $1 \mathrm{~cm}$ 程度の長さになっており, 腹部, 前胸部からも発 毛が認められてきた。第 122 日病日にはさらに発 毛を認めていたが（図 3)，その後内服薬の投与が 不十分な時期が多くなり, 第 176 病日の時点では 全体の毛質の低下, 澒部周辺および背部に部分的 な脱毛の進行を認めた。しかしながら, 炎処置部 位は発毛したままであり，第 1 病日，第 39 病日， 第 87 病日，第 123 病日の処置部位にそれぞれ，9 


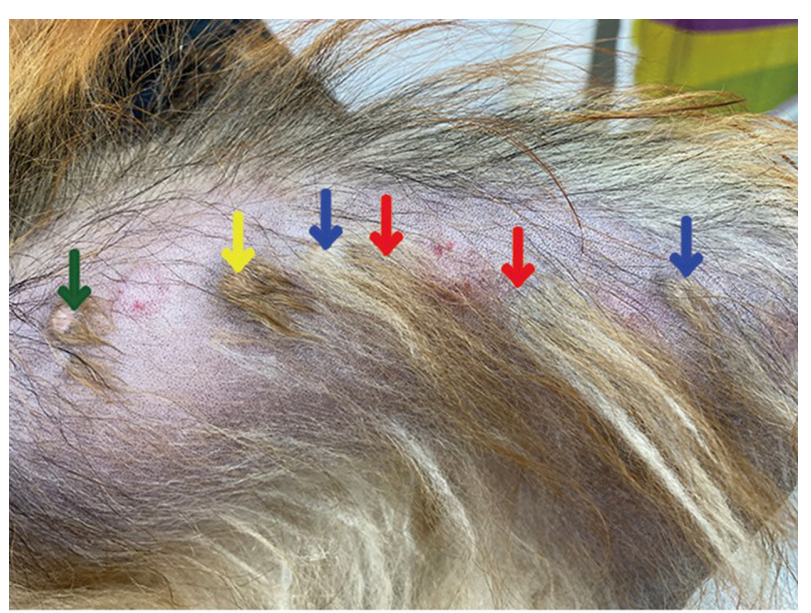

$\downarrow$ 第 1 病日炎処置部

$\downarrow$ 第 39 病日炎処置部

\section{第 87 病日炎処置部}

\section{$\downarrow$ 第 122 病日炎処置部}

図 4 第 176 病日の臨床所見. 様々な長さでの発毛が認 められた

$\mathrm{cm}, 4 \mathrm{~cm}, 2 \mathrm{~cm}, 1 \mathrm{~cm}$ 弱の被毛を認め, 処置した 時系列がわかるような状態となった（図 4)。また, 第 87 病日に完全血球計算, 血液生化学検査, 尿検 査を行ったが異常は認められなかった。

本症例では炎処置後に処置部位に限局的な発毛 を認めたため，尒による刺激がマウスにおいて発 毛効果を認めたように，本症例においても温熱刺 激が組織的な変化を誘発し発毛に至った可能性が 示唆された。一方で, 処置部周辺や腹部, 前胸部 に扔いても発毛を認めたことは，治療開始時に開 始した他の併用治療の効果である可能性と, 炎に よって深部組織の血行が促進された結果, 広範囲 に発毛効果を示した可能性の両者が考えられた。
特に，炎処置部位周辺の発毛が多かった点に関し ては，炎が直接的な皮膚表面の刺激による発毛効 果だけでなく, 処置部周辺まで広範囲に発毛効果 を示した可能性が示唆された。また, 他の併用薬 の効果もしくは尒との相乗効果によって発毛を認 めた可能性も考えられた。

本症例では，尒の処置部位に紅斑および微小な 痂皮を認めたが，症例が強く痛がる様子は認めな かったことから，一般的に全身麻酔下での処置が 必要となるマイクロニードル法と比較して, 炎に よる発毛治療はより低侵襲な治療であると考えら れた。また，本症例においては経穴（ツボ）とは 無関係に発毛が認められており, 中医学の知識に 頼らずとも，一定の効果が得られる処置が可能で ある可能性が示唆された。以上のことより，毛周 期停止の症例に対して, 炎を用いた発毛治療も適 応となる可能性が示唆された。一方で, 毛周期停 止の犬に対する尒の有効性抢よび安全性に関して は，さらなる症例集積が必要であると考えられた。

\section{利益相反}

すべての著者は開示すべき利益相反はない。

\section{引用文献}

1) 形井秀一. 2012. 全日本銊尒学会雑誌 62: 12-28.

2) Miller W.H.Jr., Griffin, C.E. and Campbell, K.L. 2013. pp. 531-543. In: Muller and Kirk's Small Animal Dermatology. 7th ed. WB Saunders Co, Philadelphia.

3) 篠原昭二, 山岡傳一郎. 1999. 全日本鍼炎学会 雑誌 49: 499-529.

4) Stoll, S., Dietlin, C. and Nett-Mettler, C.S. 2015. Vet. Dermatol. 26: 387-390, e88.

5) Xu, S.L., Zhang, H.R. and Gu, Y.H. 2018. Zhen $C i$ Yan Jiu. 43: 738-743. 